Apidologie, 1984, 15 (3), 329-338.

\title{
ALTERATIONS IN HAEMOLYMPH PROTEINS OF DRONE HONEY BEE LARVAE PARASITIZED BY VARROA JACOBSONI
}

\author{
Zdzislaw GLINSKI * and Jan JAROSZ \\ $\because$ Bee Discases Laboratory, Institute of Infections and Invasive Diseases, \\ Agricultural University, Lublin \\ $*$ Unit of Insect Pathology, M. Curie-Sklodowska University, \\ Lublin, Akademicka 19, Poland
}

\begin{abstract}
SUMMARY
Protein fractions in haemolymph of normal and Varroa jacobsoni parasitized drone brood were made by two acrylamide gel electrophoresis methods. Total protein content was examined following haemolymph denaturation. Basic proteins were evaluated using a discontinuous acidic buffer system.

The studies reveal a reduction of the content of total proteins in haemolymph of parasitized drone brood that is related to the intensity of the invasion. The invasion alters both the clectrophoretic patterns and densities of blood proteins, especially of low molecular weight cathodal protein fractions. It is reasonable to assume from the results obtained that changes in spectra of haemolymph proteins are the result of protein depletion, but also could be connected with some biochemical changes following release of toxic substances of the mite into the body of the host.
\end{abstract}

\section{INTRODUCTION}

In most cases the effect of external parasitic mites on an insect host is harmful. The general pathology of invasions can involve reduction of fat body and retardation of both development and growth of the host (SHABANov et al., 1978). Moreover, research on biochemical pathology has shown that haemolymph of parasitized insects changes radically when compared to normal individuals. In general, the number and density of soluble proteins are drastically reduced. Such changes may arise as 1) the result of requirements of the parasite for particular biochemical substrates which causes an excessive drain of the haemolymph constituents ; 2) the host response to parasitic invasion by biochemical 
modification of the haemolymph constituents ; 3) the host response to secondary invasions by microorganisms (POPA, 1981); or 4) a combination of these three mechanisms.

Currently Varroa jacobsoni is receiving considerable attention as an extremely dangerous parasite of the honey bee, Apis mellifera (De JoNG et al., 1982). Varroa disease is without doubt the worst problem at the present time in world bee-keeping, and the mite is found today on all continents except Australia and North America (Marin, 1979, Morse and Goncalves, 1979).

It is well known that honey bee infected by $V$. jacobsoni are seriously harmed. Weight gain of brood is diminished, and in heavy invasions older brood and nymphs are deformed or even killed (Brizard, 1978, Grobov, 1977). Volume and total protein content are reduced and total nitrogen is increased in the haemolymph of infected bees.

In addition, in muscles of parasitized bees the content of nucleic acids is lowered by 1.5 times (Sadov, 1978).

The actual parasitation takes place nearly always on the older brood, and drone brood is prefered to worker brood (HARAGSIM, 1973). The adult bee mostly acts as an intermediate host and a means of transport of $V$. jacobsoni mite (RI'TTER, 1981).

In order to resolve some problems of the pathogenesis of Varroa disease we undertook the present comparative studies to determine the changes in haemolymph protein fractions in older drone brood (capped brood) parasitized by $V$. jacobsoni. Since preliminary data raised the possibility that $V$. jacobsoni invasion might affect not only the growth and survival of brood but also biochemical alterations of host haemolymph components, the examinations of haemolymph protein fractions of honey bee brood parasitized by $V$. jacobsoni was undertaken.

\section{MATERIALS AND METHODS}

Parasitized drone brood. The studies on the alterations in haemolymph fractions were done on drone brood taken from a colony of bees parasitized by Varroa jacolsoni. The intensity of the invasion was evaluated on the basis of the number of mites present in capped comb cells with capped drone larvae.

The specimen samples of haemolymph were obtained from the capped larvae of drones slightly (up to 3 mites) and heavily (4-6 mites) infested by Varroa jacobsoni. Larvae were bled by puncture of the dorsal cuticle with a Pasteur pipette. Aliquots of $10 \mu 1$ were withdrawn by a micropipette and then added either into $30 \mu \mathrm{l}$ of $1 \mathrm{M}$ sucrose or into $50 \mu \mathrm{l}$ of buffer according to LAEMMLI (1970). To prevent melanization blood samples had a trace of phenylthiourea added and were continously held in an ice bath. Samples of blood of uninfested drone larvae were withdrawn in the same manner. In all, 48 samples in sucrose, 32 in buffer, and 32 control samples in buffer were collected. 
Separation of blood proteins. Two distinct methods of acrylamide gel electrophoresis were used to fractionate proteins present in haemolymph of control and parasitized drone brood. The samples of blood in sucrose were separated for low molecular weight cathodal protein fractions using a discontinuous acidic buffer system by the method of ReISFELD ef al. (1962) with the following changes. A $24 \%$ and not $15 \%$ separation gel was used. Ammonium persulphate $(14 \mathrm{mg} / 20 \mathrm{ml}$ ) was used instead of riboflavin as catalyzer. Thirty microliter samples of blood sucrose mixture (equivalent to $7.5 \mu$ l the whole uncentrifuged drone blood) were always used for electrophoretic separation. Gels were stained for total proteins with $0.5 \%$ amido black solution for $1 \mathrm{~h}$ and then destained for several days with $7.5 \%$ acetic acid.

The blood samples taken in buffer were separated for total proteins under denaturating buffer system. The following changes from the method of LAEMMLI (1979) were employed. Eighteen percent and not $10 \%$ separation gel was used. Blood samples were denatured by holding in boiling water for 3 minutes. Twenty $\mu \mathrm{l}$ samples of haemolymph buffer solution (équivalent to $3.3 \mu 1$ of the haemolymph) were always gently applied on the top of the spacer gel. Gels removed from glass tubes were fixed overnight in a solution of $50 \% \mathrm{TCA}$ and stained for $24 \mathrm{~h}$ in a solution of the $0.2 \%$ Coomassie blue $\mathbf{R}-250$ in acetic acid-methanol-water (5: $14: 56, v / v)$ with $12 \%$ TCA, and then destained with several changes at one day intervals of acetic acid-methanol-water (4: $24: 56, \mathrm{v} / \mathrm{v})$.

After destaining gels were scanned at $595 \mathrm{~nm}$ in a VT-Vitation densitometer, and on the basis of the number of dots, the relative proportions of individual protein fractions were estimated. Dots are the result of a method of integration to obtain the area under the curve generated by densitometer scans.

\section{RESULTS}

In a series of experiments it was demonstrated that the pattern and density of cathodal protein fractions in haemolymph of bee larvae varies among individuals. Typical distributions and quantitative characteristics of cathodal protein fractions are shown in Fig. 1. The individual fractions of basic proteins are enumerated along a gradient of increasing electrophoretic mobility. Omitting a large band of protein that was arrested on the top of the gel, no less than 9 fractions are revealed in the blood of control larvae. It seems, moreover, that fractions numbered 4-5 and 7-8 are composed of more than two separate subunits which are not resolved under our conditions. Figures in parentheses show the relative area under the curve for nonmigrating protein fraction (top) and for cathodal proteins (bottom).

There is a clear decrease in total haemolymph protein following infestation by $V$. jacobsoni. Preliminary comparison of the proteins not migrating reveals a slight decrease in their density following infestation. On the basis of the relative area (see Fig. 1) if the control is assumed as $100 \%$ (404 dots) the value of nonmigrating fraction decreases by $13.1 \%$ in blood of slightly parasitized larvae $\left(\mathrm{V}_{1-3}\right)$ (351 dots) and by $22.5 \%$ in blood of heavily infested brood $\left(\mathrm{V}_{4-6}\right)$ (313 dots). 


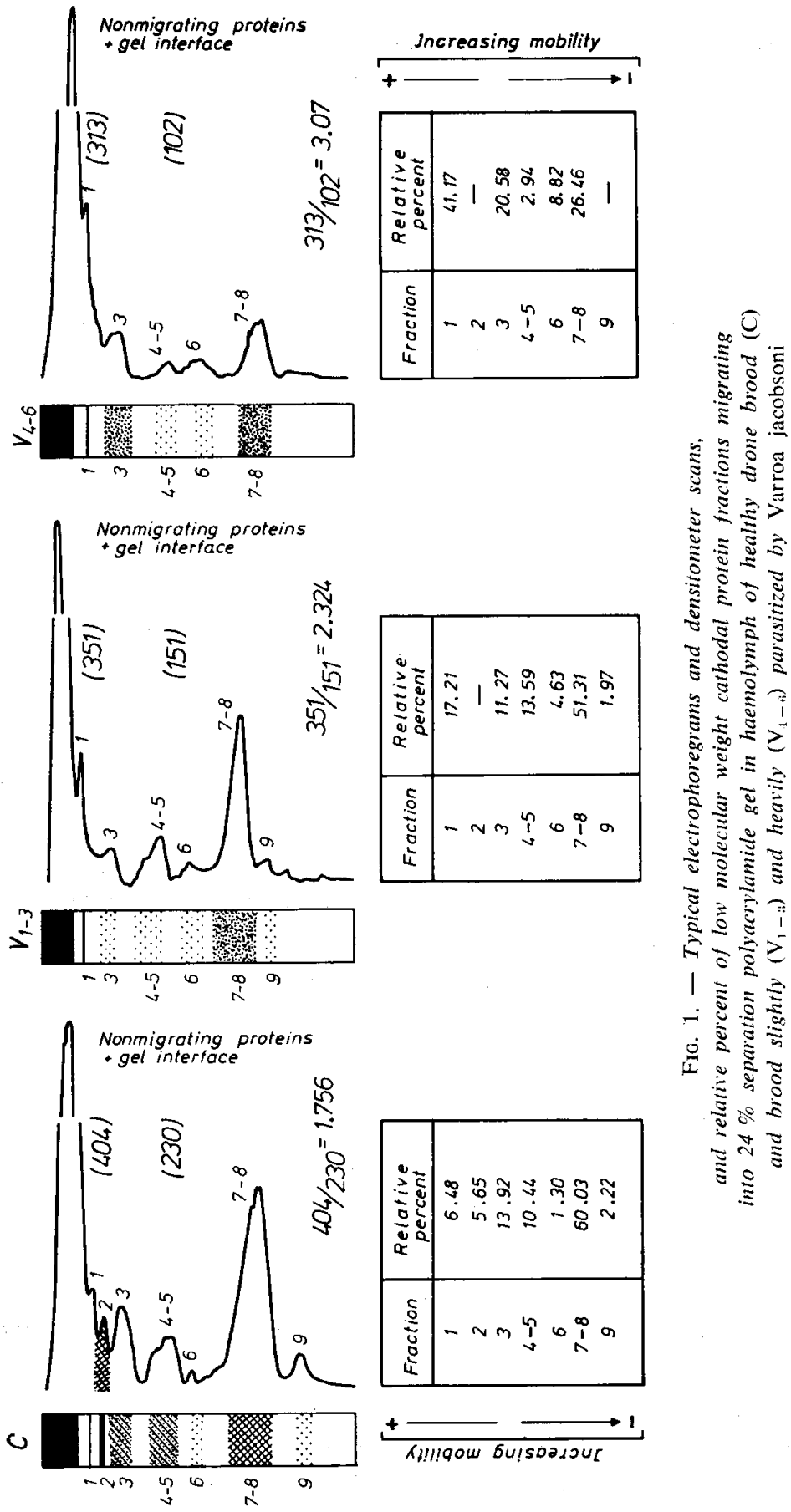


A more pronounced decrease was found when the density of low molecular weight cathodal protein fractions was compared with that of normal ones. Comparing to control larvae (C), the total amount of basic proteins decreases by about $34.3 \%$ in slightly infested $\left(\mathrm{V}_{1-3}\right)$ and by $55.6 \%$ in heavily infested brood $\left(\mathrm{V}_{4-6}\right)$, as shown in Fig. 1. Moreover, the content of migrating and nonmigrating proteins in blood of slightly and heavily parasitized larvae in comparison to control larvae diminishes by $20.8 \%$ and $34.5 \%$, respectively.

The decrease of total proteins in haemolymph of infested brood is more clearly shown using the ratio of the amount of nonmigrating proteins to migrating proteins. As it is shown in Fig. 1, this ratio increases drastically from a low value 1.75 in control brood $(\mathrm{C})$ to above 3 in blood of heavily infested drones $\left(\mathrm{V}_{4-6}\right)$.

Although the alterations in density of cathodal proteins concern all migrating fractions, the most pronounced changes are observed in faintly migrating fraction number 2 (cross-hatched area, Fig. 1) that disappears entirely in sick brood. Like fraction 2, a gradual disappearance is also noted in low molecular weight fast migrating and faintly stained fraction number 9 , which was absent in heavily infested brood $\left(\mathrm{V}_{4-6}\right)$; (Fig. 1).

On the basis of the experiments performed it is difficult to determine general alterations in the content of other basic proteins but some trends may be drawn. It is reasonable to assume that the content of fractions numbered 7-8 decreases in infected larvae, and a relative density of fraction 1 increases in sick larvae. Fractions $7-8$ decrease by about $14.5 \%$ in slightly and by $55.9 \%$ in heavily infested larvae, while fraction 1 increases in relative percent by about $300 \%$ in slightly and by about $700 \%$ in heavily parasitized brood. On the other hand, however, it seems that the absolute content of fraction 1 does not essentially alter in density in parasitized drones, and persists on the level of control blood.

Pattern of total proteins in blood of normal (C) and infested drones (V) in a typical experiment is shown in Fig. 2. On electrophoregrams the protein fractions are numbered according to increasing electrophoretic mobilities starting from the fraction of highest molecular weight. Fractions from control and infected brood do not as a rule correspond to each other. Comparison of the patterns of proteins present in haemolymph of normal and infested drones reveals great similarities. In both samples 31 or more well-defined protein fractions are found, differing only slightly by their density and relative mobility. It is difficuit to define alterations in the pattern and density of individual protein fractions after dissociation on the basis of our studies. In spite of identical denaturing conditions, certains subtle differences observed in the pattern of haemolymph proteins could however originate from parasitic invasion. It seems that subunits of proteins $12 \mathrm{a}, \mathrm{b}, \mathrm{c}$ present in control haemolymph are absent in $V$. jacobsoni infested drones, while fractions $3 \mathrm{a}, 7 \mathrm{a}$ and $25 \mathrm{a}$ and $\mathrm{b}$ are noted only in haemolymph of 


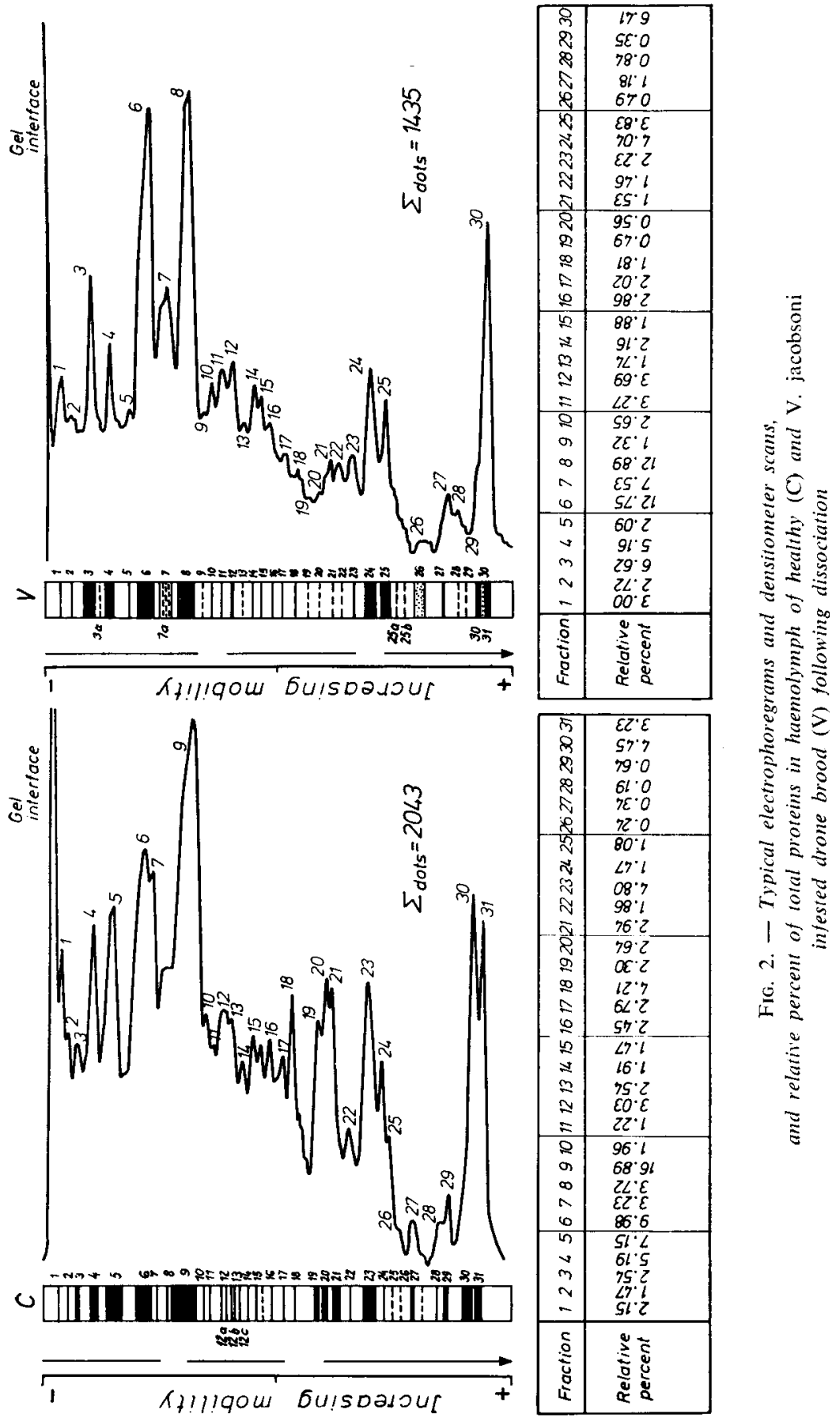


diseased drones. The total content of proteins in blood of infested drones is lower than that of unparasitized larvae. From the comparisons of the relative proportions of proteins it is computed that it decreases about $30 \%$ in sick bees.

\section{DISCUSSION}

In this paper are presented the results of the studies on alterations in protein fractions of haemolymph of drone bee brood infested by $V$. jacobsoni. Using two electrophoretic techniques, we compared the patterns and densities of basic and denaturated proteins present in blood of infested and normal drones. Distributional and quantitative comparisons of cathodal protein fractions clearly demonstrate that protein depletion is a general aspect of the biochemical pathology of $V$. jacobsoni invasion on larval drones Fig. 1. These evident alterations in proteins could not be interpreted as an effect of nutritional protein deficiency since the experiments were performed on sealed drones under natural conditions. The observed internal modifications of the protein spectra of haemolymph appear infested drones suggest that parasitism may alter the overall soluble protein compomolecular weight cathodal proteins and the pattern of protein bands in heavily to be connected with the activity of $V$. jacobsoni alone.

A decrease in total blood proteins was also observed following denaturation (see Fig. 2). These pronounced changes observed both in the density of low infested drones suggest that parasitism may alter the overall soluble protein composition of haemolymph. One can assume that these alterations result not only from the feeding of parasites on larvae but also from a release by the parasite of some substances into the body of the host, probably disturbing blood melanization during invasion (PoPA, 1981).

\section{CONCLUSIONS}

1. A remarkable reduction of the content of total proteins in haemolymph of drone brood parasitized by $V$. jacobsoni was noted. The alterations are related to the intensitiy of the invasion.

2. The invasion alters the electrophoretics patterns and densities of blood proteins, especially of low molecular weight cathodal protein fractions.

3. One can assume that the above changes in haemolymph proteins are the result of protein depletion. Also possible are biochemical changes in the content of the haemolymph proteins following release of toxic substances into the body of the host during invasion. 


\section{RÉSUME \\ MODIFICATIONS DES PROTÉINES DE L'HEMOLYMPHE \\ DES LARVES DE MALES D'ABEILLES PARASITEES PAR VARROA JACOBSONI}

Afin de résoudre certains problèmes de pathogenèse de la varroose, des études comparatives ont été entreprișes pour savoir si l'infestation par Varroa jacobsoni provoquait chez l'hôte des modifications biochimiques, en particulier dans le spectre et la densité des fractions protéiniques de l'hémolymphe du couvain mâle.

Deux méthodes d'électrophorèse sur gel d'acrylamide ont été utilisées pour fractionner les protéines de l'hémolymphe : 1) la méthode LaemmL (1970) modifiée utilisant un système tampon dénaturant, pour les protéines totales, 2) la méthode de ReISfeld et al. (1962) utilisant un système tampon acide discontinu, pour les protéines basiques de faible poids moléculaire.

L'infestation par $V$. jacobsoni provoque une diminution de la teneur générale en protéines de l'hémolymphe des mâles et modifie le spectre électrophorétique et la densité des protéines, en particulier des protéines cathodales de faible poids moléculaire. Les modifications qualitatives et quantitatives sont en rapport avec le degré d'infestation des mâles par l'acarien. Par rapport au témoin (couvain mâle non parasité), la fraction non migrante, séparée dans la méthode de ReISFeld et al. par le gel à $24 \%$, diminue de $13,1 \%$ chez les larves légèrement parasitées (LP) (jusqu'à 3 acariens/larve) et de 22,5\% chez les larves fortement parasitées (FP) (4-6 acariens/larve). La quantité totale de protéines migrantes est réduite de $34,3 \%$ chez le couvain LP et de $55,6 \%$ chez le couvain FP.

Bien que l'on trouve chez toutes les protéines migrantes des modifications dans la densité des protéines cathodiques une réduction particulièrement élevée a été notée pour la fraction $n^{\circ} 2$ faiblement migrante, qui est totalement absente chez le couvain malade. De même on a observé une forte diminution de la fraction $\mathrm{n}^{\circ} 9$, fortement migrante et de faible poids moléculaire qui, elle aussi, manque totalement chez le couvain FP.

Les spectres et densités des protéines après dissociation sont fortement semblables chez le couvain sain et le couvain parasité, bien que la densité des fractions soit notablement réduite chez ce dernier, d'environ $30 \%$.

Il est finalement difficile de déterminer des modifications générales et on peut raisonnablement penser que les changements qualitatifs et quantitatifs dans le spectre des protéines de l'hémolymphe sont non seulement le résultat d'une diminution des protéines, mais peuvent aussi être liés à certains effets biochimiques, suite à la libération de substances toxiques par $V$. jacobsoni dans l'hémocèle du couvain mâle d'abeilles.

\section{ZUSAMMENFASSUNG}

\section{EIN VERSUCH ZUR BESTIMMUNG DER VERÄNDERUNGEN IN DEN HAEMOLYMPH-PROTEINEN VON DROHNEN LARVEN, PARASITIERT DURCH VARROA JACOBSONI}

In den vergangenen Jahren ist die Varroatose zu einem der größten Probleme der Bienenhaltung geworden. Der Auslöser der Seuche, die Milbe Varroa jacobsoni, ist ein Exoparasit der Honigbienen und der Bienenbrut. Er versursacht große Blutverluste bei den Bienen, die zu extensiven Schäden bis hin zur Ausrottung des Wirts führen können. Unter Berücksichtigung der Pathogenese der Varroatose erschien es interessant $\mathrm{zu}$ untersuchen, ob die Parasitierung eine Anderung der Proteinmuster und deren Dichte in der Haemolymphe von Drohnenlarven bewirkt.

Zur allgemeinen Proteinbestimmung wurde die SDS-Diskelektrophorese nach LaEMMLI (1970) benutzt. Um die Veränderungen der Basisproteine und Polypeptidfraktionen erfassen zu können, 
wurde dic Methode von Reısfeld et al. (1962) von uns so abgeändert, daß sie auch die Trennung von Basisproteinen mit niedrigem Molekulargewicht erlaubt.

Der Varroabefall erniedrigt den totalen Proteingehalt in der Haemolymphe der Drohnen, ändert das Elektrophoresemuster und die Dichte der Proteinfraktionen besonders in den KathodenProtein-Fraktionen mit niedrigem Molekulargewicht. Proteinmuster und -dichte waren abhängig vom Befallsgrad. Im Vergleich zu nichtbefallener Drohnenbrut reduzierte sich der Anteil der nichtwandernden Fraktion bei den leichter befallenen Larven (bis zu 3 Milben pro larve) um 13,1\% (Methode nach ReISFELD et al., 1962) bei starkem Befall (4-6 Milben pro Larve) um $22,5 \%$. Der Vergleich der wandernden Proteine ergab eine Reduzierung um 34,3\% bei leicht infizierten und um 55,6\% bei stark infizierten Drohnenlarven. Die nur wenig wandernde Fraktion $\mathrm{Nr} .2$ verschwand bei infizierter Brut vollständig. Auch die Fraktion Nr, 9 aus der Kathoden-Protein-Fraktion verschwand mit zunehmendem Befallsgrad der Brut.

Vergleichende Untersuchungen der Proteinmuster von infizierter und nichtinfizierter Drohnenbrut nach Dissoziation ergaben weitgehende Übereinstimmung. Die totale Dichte von 31 oder mehr einzeln betrachteten Fraktionen von parasitierter Brut war um ca. $30 \%$ erniedrigt gegenüber der Dichte von Fraktionen aus der Haemolypmphe von nicht befallener Brut. Einschränkend muß jedoch gesagt werden, daß die vorliegenden Experimente und Elektrophorogramme es noch nicht zulassen, ultimativ über die Veränderungen im Muster und der Dichte von einzelnen Proteinfraktionen zu entscheiden.

Ausgehend von den vorhandenen Resultaten kann man jedoch annehmen, dal3 die Veränderungen in der Verteilung und der Menge im Spektrum der Haemolymph-Proteine nicht nur ein Ergebnis des Proteinverlusts sind. Denkbar wären auch biochemische Effekte z.B. als Folge der Abgabe von toxischen Substanzen durch die Milbe in die Haemolymphe des Wirtes.

\section{REFERENCES}

Brizard A., 1978. - Une maladie grave des abeilles : la varroase. Rel. Méd. Vét., 129, 1473-1489. De Jong D., Morse R.A., Eickwort G.C., 1982. - Mite pests of honey bees. Ammu. Rev. Entomol., 27, 229-252.

Domackaja T.F., 1980. - Pokaziteli gemolimfy u pczel pri varroozie. Veterinaria (Moscow), 11, 47-53.

Gronov C.F., 1977. - La varroase des abeilles. In : La varroase, maladie de labeille mellifère. Bucarest, ed. Apimondia, 52-78.

Haragsim O., 1974. - The mite Varroa jacobsoni as a threat to beekeeping in Europe. Imkerfreund, 28, 316-317.

LAEMMLI U.K., 1970. - Cleavage of structural proteins during the assembly of the head of bacteriophage $\mathrm{T}_{1}$. Nature, 227, 680-685.

Marin M., 1979. - La dynamique de l'évolution mondiale de la varroatse Apinomdia, 2, $27-30$.

Morse R.A., Goncalves L.S., 1979. - Varroa disease, a threat to world beekeeping. Gleam. Bee Cult., 107, 179-181, 202.

PopA A., 1981. - Sur la varroase des abeilles. Bull. Off. int. Epiz., 93, 1423-1438.

Reisfeid R.A., Lewis U.T., Williams E., 1962. - Disc electrophoresis of basic proteins and peptides on polyacrylamide gels. Nature, 195, 282-283.

Ritter W., 1981. - Varroatosis, a new disease of the bee Apis mellifera. Anim. Res. Development, 14, 17-35.

Sadov A., 1978. - Vlijanje kleszcza Varroa jacobsoni na biochimiczeskije pokazitieli pczel. Veterinarija Moscon', 9, 67-70.

Shabanov M., Nedealkov S., Toshkov A., 1978. - Varroatosis - a dangerous parasitic disease of bees. Am. Bee. J., 118, 402-403, 407. 